\title{
Photosynthetic energy conversion under extreme conditions-II: the significance of lipids under light limited growth in Antarctic sea ice diatoms
}

\author{
Thomas Mock ${ }^{\mathrm{a}, *}$, Bernd M.A. Kroon ${ }^{\mathrm{a}, \mathrm{b}}$ \\ a Alfred-Wegener-Institute for Polar and Marine Research, Am Handelshafen 12, D-27570 Bremerhaven, Germany \\ ${ }^{\mathrm{b}}$ KroonAqa GmbH, Knurrhahnstraße 9, D-27572 Bremerhaven, Germany
}

Received 14 December 2001; received in revised form 2 May 2002

\begin{abstract}
Low photosynthetic active radiation is a strong determinant in the development and growth of sea ice algae. The algae appear to have universal mechanisms to overcome light limitation. One important process, which is induced under light limitation, is the desaturation of chloroplast membrane lipids. In order to discover whether this process is universally valid in sea ice diatoms, we investigated three species coexisting in chemostats illuminated with 15 and $2 \mu$ mol photons $\mathrm{m}^{-2} \mathrm{~s}^{-1}$ at $-1^{\circ} \mathrm{C}$. Growth under $2 \mu \mathrm{mol}$ photons $\mathrm{m}^{-2} \mathrm{~s}^{-1}$ caused a $50 \%$ increase in monogalactosyldiacylglycerols (MGDG) thylakoid membrane related 20:5 $n-3$ fatty acids. This fatty acid supports the fluidity of the thylakoid membrane and therefore the velocity of electron flow, which is indicated by increasing rate constants for the electron transport between $\mathrm{Q}_{\mathrm{A}}$ (first stable electron acceptor) and bound $\mathrm{Q}_{\mathrm{B}}$ (second stable electron acceptor) (11.16 \pm 1.34 to $23.24 \pm 1.35$ relative units). Two $\mu$ mol photons $\mathrm{m}^{-2} \mathrm{~s}^{-1}$ furthermore resulted in higher amounts of non-lipid bilayer forming MGDG in relation to other bilayer forming lipids, especially digalactosydiacylglycerol (DGDG). The ratio of MGDG:DGDG increased from $3.4 \pm 0.3$ to $5.7 \pm 0.3$. The existence of bilayer thylakoid membranes with high proportions of non. bilayer forming lipids is only possible when sufficient thylakoid pigment-protein complexes are present. If more thylakoid pigment-protein complexes are present in membranes, as found under extreme light limitation, less bilayer forming lipids such as DGDG are required to stabilize the bilayer structure. Differences in protein contents between both light intensities were not found. Consequently pigment contents which nearly doubled under $2 \mu \mathrm{mol}$ photons $\mathrm{m}^{-2} \mathrm{~s}^{-1}$ must be responsible in balancing the potential stability loss resulting from an increase in MGDG:DGDG ratio. (C) 2002 Elsevier Science Ltd. All rights reserved.
\end{abstract}

Keywords: Bacillariophyceae; Carbohydrates; Fluorescence induction; Lipids; Low temperature; Pigments; Proteins; Sea ice

\section{Introduction}

A number of sea ice diatom species coexist in the narrow space of brine channels (Krembs et al., 2000). This habitat is characterized by extreme conditions (low light intensities, low temperature, high salinities and limited supply of nutrients) which are strong selection factors for diatom species. Thus, only those species persist in this polar ecosystem which are able to acclimate or adapt (Kirst and Wiencke, 1995). The species probably all have the same mechanisms, which govern their success and differ from those in temperate or even tropical species. Species specific dominance in sea ice is

* Corresponding author. Tel.: +49-471-48-31-18-93; fax: +49-47148-31-425.

E-mail address: tmock@awi-bremerhaven.de (T. Mock). probably related to small intraspecific differences (Huisman and Weissing, 1999) in e.g. salinity and temperature tolerance. In order to find universal mechanisms of regulation underlying these small intraspecific differences, we studied three dominant coexisting Antarctic sea ice diatoms by growing them in chemostats at $-1{ }^{\circ} \mathrm{C}$ and two subsaturating light intensities. Low light acclimation is a universal physiological process, dependent on the structure and function of the photosynthetic apparatus. Photosystems and their subcomplexes, e.g. LHC (light harvesting complex), D1 (reaction center protein of photosystem II), D2 (reaction center protein of photosystem II), are anchored within the thylakoid membrane through lipids which are exclusively present in the chloroplast. This close connection between lipids and photosystem subcomplexes indicate an interdependence between both, which supports the concept of photo- 


\begin{tabular}{|c|c|c|c|}
\hline \multicolumn{2}{|c|}{ Nomenclature } & $C$ & $\begin{array}{l}\text { saturation flashes at a rate of } K_{B} \\
\text { fraction of PS II characterized by a slow }\end{array}$ \\
\hline $\mathrm{RC}$ & reaction centre & & decay after \\
\hline PS II, I & photosystem II, I & & saturation flashes at a rate of $K_{C}$ \\
\hline $\mathrm{LHC}$ & light harvesting complex & $P$ vs $I$ & photosynthesis $(P)$ versus irradiance $(I)$ \\
\hline $\mathrm{D} 1 / \mathrm{D} 2$ & PS II reaction centre proteins & $\alpha$ & light limited slope of the $P$ vs $I$ curve/ \\
\hline $\mathrm{Q}_{\mathrm{A}}$ & quinone $\mathrm{A}$, first stable electron acceptor & & light utilization effiziency \\
\hline & of PS II & $\mathrm{Ik}$ & light level at which photosynthesis satu- \\
\hline $\mathrm{Q}_{\mathrm{B}}$ & $\begin{array}{l}\text { quinone B, second stable electron } \\
\text { acceptor }\end{array}$ & $P_{\max }$ & $\begin{array}{l}\text { rates } \\
\text { maximum rate of photosynthesis }\end{array}$ \\
\hline$F$ & $\begin{array}{l}\text { fluorescence. Subscripts o, } v, m \text { repre- } \\
\text { sent the fluorescent level during light }\end{array}$ & $K$ & $\begin{array}{l}\text { rate constant for fluorescence decay } \\
\text { measurements }\end{array}$ \\
\hline & $\begin{array}{l}\text { induction at the origin, variable and } \\
\text { maximum levels, respectively }\end{array}$ & $A, B, C_{\mathrm{comp}}$ & $\begin{array}{l}\text { amplitudes of fluorescence decay rate } \\
\text { constants }(K)\end{array}$ \\
\hline$F_{v} / F_{m}$ & quantum yield & $J_{\text {con }}$ & connectivity between reaction centres \\
\hline$q$ & reaction centers & & (PS II) \\
\hline$p$ & connectivity between PS II units & FA & fatty acid \\
\hline$\Phi_{\mathrm{f}}$ & fluorescence yield & PUFA & polyunsaturated fatty acid \\
\hline$\Phi_{\mathrm{P}}$ & quantum yield & MGDG & monogalactosyldiacylglycerol \\
\hline$q 1$ & open reaction centres & DGDG & digalactosyldiacylglycerol \\
\hline$q 0$ & closed reaction centres & $\mathrm{PC}$ & phosphatidylcholine \\
\hline$\sigma$ & effective cross section of PS II & PG & phosphatidylglycerol \\
\hline$A$ & fraction of PS II characterized by a fast & $\mathrm{PE}$ & phosphatidylethanolamin \\
\hline & fluorescence decay after turnover & PI & phosphatidylinositol \\
\hline & saturation flashes at a rate of $K_{A}$ & TAG & triacylglycerol \\
\hline$B$ & $\begin{array}{l}\text { fraction of PS II characterized by a } \\
\text { middle fluorescence decay after turnover }\end{array}$ & SQDG & sulfoquinovosyldiacylglycerol \\
\hline
\end{tabular}

synthesis regulation by changes in the thylakoid membrane structure or the entire chloroplast. Thus, lipids have to be included into our concept of light acclimation of photosynthesis. An increase in membrane fluidity at low temperatures is essential to sustain diffusivity of gases, mobile electron and proton carriers like plastoquinone (PQ) and to repair low-temperature photoinhibition damage (e.g. Russel, 1997; Saruwatari et al., 1999; Reay et al., 1999). Apart from temperature, the strong seasonality of irradiance in polar regions plays an important role in photoautotrophic life, particularly in marine habitats where water turbulence determines the supply of photons. Some investigators have observed changes in lipid or fatty acid (FA) quality during light acclimation of algae and plants in addition to quantitative changes in chloroplast lipids (Pohl and Zurheide, 1979; Harwood and Jones, 1989; Sewon et al., 1997; Klyachko-Gurvich et al., 1999). This change is more distinct in combination with low temperatures (Tasaka et al., 1996). Ice diatoms are therefore well suited to study regulation of photosynthesis on the basis of lipid metabolism which is expected to be similar for the dominant diatom species. Special attention is therefore given to lipids as structural modulators of photosystem II efficiency as well as regulators of energy flow in three Antarctic sea ice diatoms.

\section{Results}

\subsection{Physiology}

The maximum attainable algal growth rate was strongly influenced by photon flux density. At $2 \mu \mathrm{mol}$ photons $\mathrm{m}^{-2} \mathrm{~s}^{-1}$ the algae grew at a rate of 0.17 day $^{-1}$ whereas the exposure to $15 \mu \mathrm{mol}$ photons $\mathrm{m}^{-2} \mathrm{~s}^{-1}$ lead to a rate of $0.55 \mathrm{day}^{-1}$. The strong light limitation at 2 $\mu \mathrm{mol}$ photons $\mathrm{m}^{-2} \mathrm{~s}^{-1}$ resulted in an exceptional photophysiological acclimation, which was indicated by photosystem (PS) II related parameters as well as pigment concentrations. Fluorescence measurements were based on DCMU (3-(3,4-dichlorophenyl)-1,1-dimethylurea, $20 \mu \mathrm{mol} 1^{-1}$ final concentration) induction kinetics, which reveal the potential maximum of photosynthetic performance and not the in situ kinetics. Basic analysis of PS II related parameters (Table 1) resulted in an increase in connectivity between reaction centres of ca. $50 \%$ under $2 \mu \mathrm{mol}$ photons $\mathrm{m}^{-2} \mathrm{~s}^{-1}$. Relative values for energy trapping by open reaction centres were higher under $2 \mu \mathrm{mol}$ photons $\mathrm{m}^{-2} \mathrm{~s}^{-1}$ than under $15 \mu \mathrm{mol}$ photons $\mathrm{m}^{-2} \mathrm{~s}^{-1}$. Reoxidation of $\mathrm{Q}_{\mathrm{A}}$ (primary electron acceptor) increased at $2 \mu \mathrm{mol}$ photons $\mathrm{m}^{-2} \mathrm{~s}^{-1}$ for the fast $\left(K_{A}\right)$, middle $\left(K_{B}\right)$ and slow $\left(K_{C}\right)$ component of fluorescence decay measurements after 
Table 1

Fluorescence variables for growth under $15 \mu \mathrm{mol}$ photons $\mathrm{m}^{-2} \mathrm{~s}^{-1}$ $\left(0.55 \mathrm{day}^{-1}\right)$ and $2 \mu \mathrm{mol}$ photons $\mathrm{m}^{-2} \mathrm{~s}^{-1}\left(0.17\right.$ day $\left.^{-1}\right)$ : connectivity $\left(J_{\text {con }}\right)$ between reaction centres $(\mathrm{RC})$, open $\left(K_{\text {open }}\right) \mathrm{RC}$ and quantum yield are based on DCMU induction measurements

\begin{tabular}{lll}
\hline Variable & $15 \mu \mathrm{mol}$ photons $\mathrm{m}^{-2} \mathrm{~s}^{-1}$ & $2 \mu \mathrm{mol}$ photons $\mathrm{m}^{-2} \mathrm{~s}^{-1}$ \\
\hline$J_{\text {con }}$ & $0.341 \pm 0.010$ & $0.663 \pm 0.008$ \\
$K_{\text {open }}$ & $0.408 \pm 0.015$ & $0.539 \pm 0.023$ \\
$F v / F m$ (yield) & $0.337 \pm 0.009$ & $0.398 \pm 0.010$ \\
$K_{A}\left(\mathrm{~ms}^{-1}\right)$ & $11.16 \pm 1.34$ & $23.24 \pm 1.35$ \\
$K_{B}\left(\mathrm{~ms}^{-1}\right)$ & $0.42 \pm 0.12$ & $0.96 \pm 0.22$ \\
$K_{C}\left(\mathrm{~ms}^{-1}\right)$ & $0.02 \pm 0.02$ & $0.07 \pm 0.03$ \\
$r^{2}(n=5)$ & 0.966 & 0.978
\end{tabular}

Fluorescence decay rate constants for fast $K_{A}$, middle $K_{B}$ and slow $K_{C}$ component. Values are given as relative units; $n=5 ; r^{2}=$ model fit.

saturating light flashes. The fast $(<10 \mathrm{~ms})$ phase is attributed to electron transport from $\mathrm{Q}_{\mathrm{A}}$ to $\mathrm{Q}_{\mathrm{B}}$ (second electron acceptor) in PS II reaction centers that possess bound $\mathrm{Q}_{\mathrm{B}}$. The middle phase $(10-50 \mathrm{~ms})$ is thought to represent those reaction centers that had no bound $\mathrm{Q}_{\mathrm{B}}$ before the saturating light flashes. Thus this phase may indicate the kinetics of equilibration of PQ binding to the $\mathrm{Q}_{\mathrm{B}}$ site of D1 protein of PS II. The third, very slow component ( $>50 \mathrm{~ms}$ ) seems to represent the decay of PS II centres that are unable to transmit electrons to the PQ pool. The slow $\mathrm{Q}_{\mathrm{A}}$ reoxidation apparent from this phase is thought to result from recombination between $\mathrm{Q}_{\mathrm{A}}$ and the water oxidation system in the $\mathrm{S}_{2}$ state. Thus, electron transport is faster under $2 \mu \mathrm{mol}$ photons $\mathrm{m}^{-2} \mathrm{~s}^{-1}$ and this is not caused by increasing amounts of $\mathrm{Q}_{\mathrm{B}}$ bound to $\mathrm{Q}_{\mathrm{A}}$, which is indicated by the fluorescence amplitude of $K_{A}$ ( $\left.A_{\text {comp }}\right)$ the most important process for electron flow. $A_{\text {comp }}$ remains relatively constant for both photon flux densities (0.012 and 0.011 for 15 and $2 \mu \mathrm{mol}$ photons $\mathrm{m}^{-2} \mathrm{~s}^{-1}$, respectively). Whereas $B_{\text {comp }}$ increased under $2 \mu \mathrm{mol}$ photons $\mathrm{m}^{-2} \mathrm{~s}^{-1}$ (Table 2). These amounts of bound $\mathrm{Q}_{\mathrm{B}}$ were not influenced by dark adaptation of samples for 30 min, which revealed the comparison to measurements made only $90 \mathrm{~s}$ after sampling. The differences between PS II related parameters for both light intensities lead to differences in quantum yield and thus low

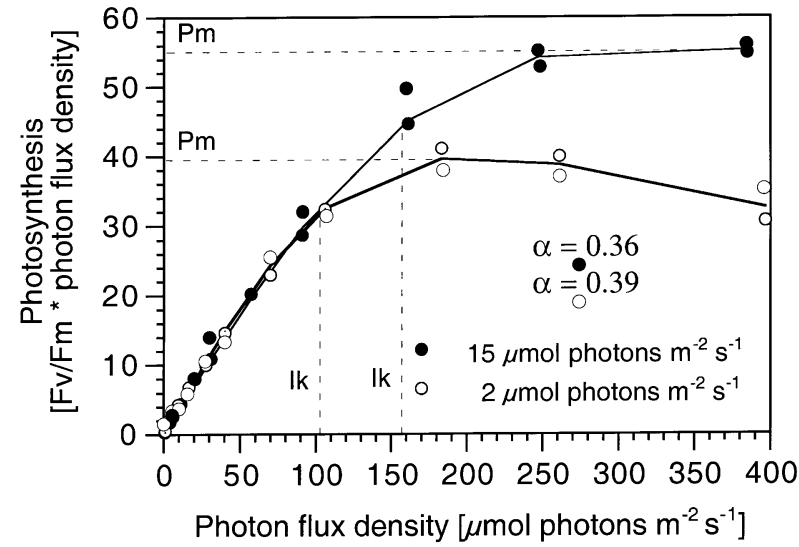

Fig. 1. Photosynthesis as $F_{v} / F_{m}{ }^{*}$ photon flux density vs irradiance in ice diatoms under $15 \mu \mathrm{mol}$ photons $\mathrm{m}^{-2} \mathrm{~s}^{-1}\left(\mu=0.55\right.$ day $\left.^{-1}\right)$ and 2 $\mu \mathrm{mol}$ photons $\mathrm{m}^{-2} \mathrm{~s}^{-1}\left(\mu=0.17 \mathrm{day}^{-1}\right)$ are based on DCMU induction measurements. Photosynthetic parameters $\alpha$ (light utilization efficiency), Ik (quantum flux of PAR at onset of light saturation), Im (quantum flux of PAR for maximum of photosynthesis), Pm (maximum photosynthetic rate) were calculated after Eilers and Peeters (1988); $n=2$.

light acclimation (Fig. 1). Maximum attainable photosynthetic rate (55-40 relative values) as well as the light level at which photosynthesis saturates $(159-101 \mu \mathrm{mol}$ photons $\mathrm{m}^{-2} \mathrm{~s}^{-1}$ ) decreased whereas $\alpha$ (light utilization effiziency defined as the slope of photosynthesis vs irradiance curve; Fig. 1) increased (0.36-0.39) under $2 \mu \mathrm{mol}$ photons $\mathrm{m}^{-2} \mathrm{~s}^{-1}$. This typical photosynthetic response under low light acclimation is also supported by changes in relative pigment concentration (Fig. 2).

Pigments constituted a large proportion $( \pm 70 \%)$ of total cell carbon under $2 \mu \mathrm{mol}$ photons $\mathrm{m}^{-2} \mathrm{~s}^{-1}$, resulting in a carbon:chlorophyll (chl) $a$ ratio of 3.5. However, only $30 \%$ of total algal carbon was represented by pigments in the $15 \mu \mathrm{mol}$ photons $\mathrm{m}^{-2} \mathrm{~s}^{-1}$ incubation resulting in a carbon:chl $a$ ratio of 7.4. No significant change in relative pigment ratios was observed compared to the major other lipids with exception of diadinoxanthin. Diadinoxanthin concentrations were reduced under $2 \mu \mathrm{mol}$ photons $\mathrm{m}^{-2} \mathrm{~s}^{-1}$, which caused a strong reduction in pigment ratios. Diadinoxanthin:chl

Table 2

Amplitudes of fluorescence decay rate constants for fast $K_{A}\left(A_{\text {comp }}\right)$, middle $K_{B}\left(B_{\text {comp }}\right)$ and slow $K_{C}\left(C_{\text {comp }}\right)$ component for growth under $15 \mu$ mol photons $\mathrm{m}^{-2} \mathrm{~s}^{-1}\left(0.55 \mathrm{day}^{-1}\right)$ and $2 \mu \mathrm{mol}$ photons $\mathrm{m}^{-2} \mathrm{~s}^{-1}\left(0.17\right.$ day $\left.^{-1}\right)$

\begin{tabular}{|c|c|c|c|c|}
\hline \multirow[t]{2}{*}{ Variable } & \multicolumn{2}{|c|}{$15 \mu \mathrm{mol}$ photons $\mathrm{m}^{2} \mathrm{~s}^{-1}$} & \multicolumn{2}{|c|}{$2 \mu \mathrm{mol}$ photons $\mathrm{m}^{2} \mathrm{~s}^{-1}$} \\
\hline & $90 \mathrm{~s}$ & $30 \mathrm{~min}$ & $90 \mathrm{~s}$ & $30 \mathrm{~min}$ \\
\hline \multirow[t]{2}{*}{$A_{\text {comp }}$} & 0.011 & 0.012 & 0.016 & 0.011 \\
\hline & 0.012 & 0.012 & 0.012 & 0.012 \\
\hline \multirow[t]{2}{*}{$B_{\text {comp }}$} & 0.006 & 0.004 & 0.017 & 0.018 \\
\hline & 0.010 & 0.006 & 0.017 & 0.013 \\
\hline \multirow[t]{2}{*}{$C_{\text {comp }}$} & 0.001 & 0.001 & 0.004 & 0.001 \\
\hline & 0.001 & 0.001 & 0.006 & 0.001 \\
\hline
\end{tabular}

They were determined $90 \mathrm{~s}$ and 30 min after sampling; $n=2$. 


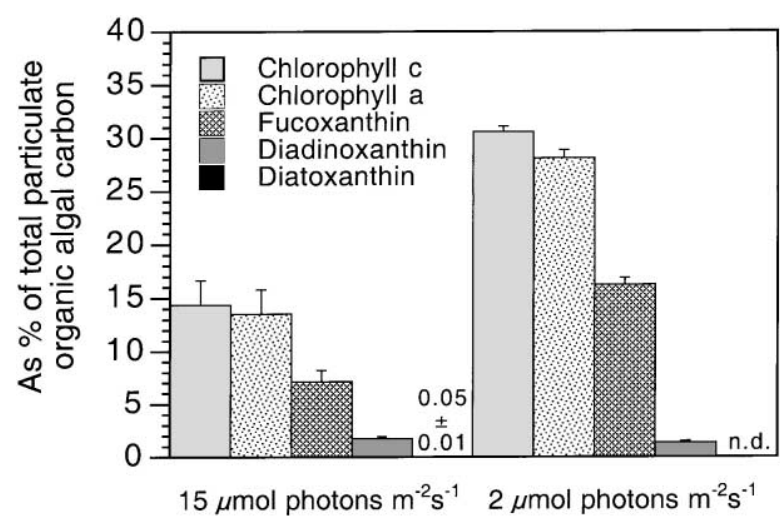

Fig. 2. Pigment composition of sea ice diatoms as $\%$ at total particulate organic algal carbon under 15 and $2 \mu \mathrm{mol}$ photons $\mathrm{m}^{-2} \mathrm{~s}^{-1}$ with corresponding growth rates of 0.55 and $0.17 \mathrm{day}^{-1}$, respectively. Carotene was always below detection limit. Error bars denote standard deviations; n.d. $=$ not detectable; $n=3$.

$a$ ratio was 0.14 at $15 \mu \mathrm{mol}$ photons $\mathrm{m}^{-2} \mathrm{~s}^{-1}$ and 0.04 at 2 $\mu \mathrm{mol}$ photons $\mathrm{m}^{-2} \mathrm{~s}^{-1}$. Diatoxanthin as well as $\beta$-carotene represented less than $0.5 \%$ of total algal carbon.

\subsection{Biochemistry}

Macromolecular composition of diatoms was influenced by the availability of light (Fig. 3). Carbohydrates, as primary assimilates were reduced at $2 \mu \mathrm{mol}$ photons $\mathrm{m}^{-2} \mathrm{~s}^{-1}$ whereas proteins and lipids remained unaffected under both applied photon flux densities. This is also the case for the membrane lipid fraction as well as for storage lipids of which the latter only represented a small proportion of total algal lipids (17\%) (Fig. 4). The dominant membrane lipid class of ice diatoms under light limitation was MGDG, which is exclusively present in chloroplasts, particularly in thylakoid membranes (Fig. 5). DGDG as well as SQDG are also restricted to chloroplasts, whereas phospholipids also occur in non-chloroplast membranes.

The dominance of MGDG indicates that chloroplast membranes were the most abundant membranes in the cell. The most obvious effect of the reduction in irradiance on membrane lipid composition was an increase in MGDG:DGDG ratio to the unexpectedly high ratio of 5.6 at $2 \mu \mathrm{mol}$ photons $\mathrm{m}^{-2} \mathrm{~s}^{-1}$ (Fig. 6). Fatty acid composition of the different membrane lipid classes as well as storage lipids was influenced by photon flux density. The proportion of polyunsaturated fatty acids (PA) (PUFA) at $2 \mu \mathrm{mol}$ photons $\mathrm{m}^{-2} \mathrm{~s}^{-1}$ increased for all lipid classes with a concominant decrease of monounsaturated FA (MUFA) and saturated FA (SAFA), except for DGDG. Here, the fatty acid composition remained unchanged for both photon flux densities (Fig. 7). The strongest reduction of saturated FAs in all lipid classes except DGDG could be observed for 14:0 and 16:0 FAs at $2 \mu \mathrm{mol}$ photons $\mathrm{m}^{-2} \mathrm{~s}^{-1}$. The PUFA $20: 5$ increased by at least $38 \%$ in phosphatidylcholine

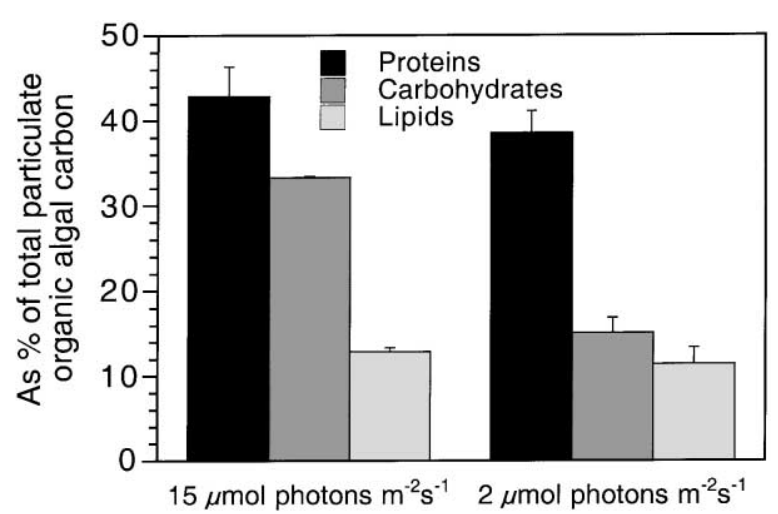

Fig. 3. Macromolecular composition of sea ice diatoms as $\%$ of total particulate organic algal carbon under 15 and $2 \mu \mathrm{mol}$ photons $\mathrm{m}^{-2} \mathrm{~s}^{-1}$ with corresponding growth rates of 0.55 and 0.17 day $^{-1}$, respectively. Error bars denote standard deviations; $n=3$.

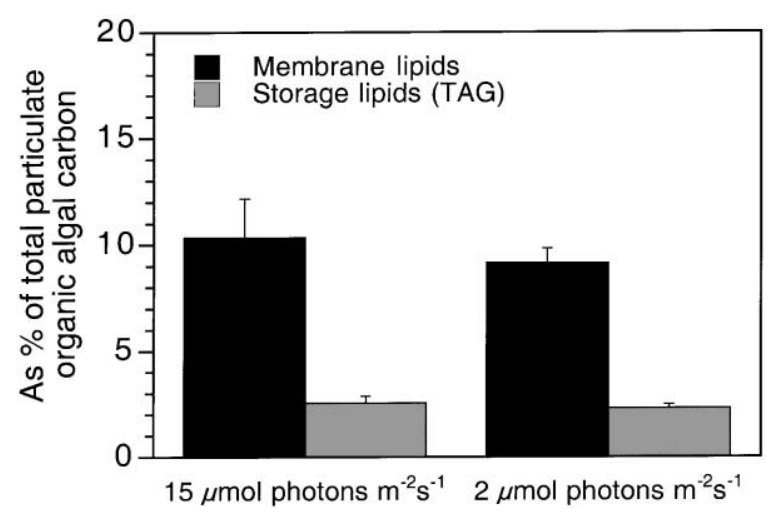

Fig. 4. Polar membrane lipids and storage lipids (triacylglycerol TAG) as $\%$ of total particulate organic algal carbon under 15 and 2 $\mu \mathrm{mol}$ photons $\mathrm{m}^{-2} \mathrm{~s}^{-1}$ with corresponding growth rates of 0.55 and 0.17 day $^{-1}$, respectively. Error bars denote standard deviations; $n=3$.

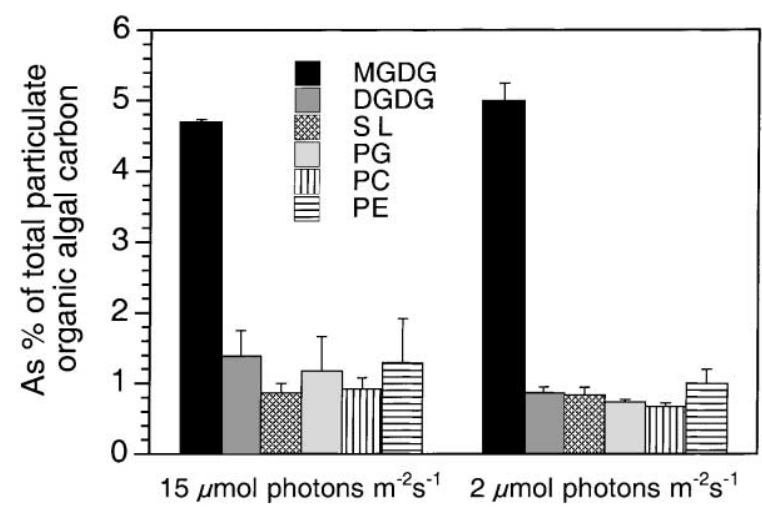

Fig. 5. Glyco- and phospholipid classes of sea ice diatoms as \% of total particulate organic algal carbon under 15 and $2 \mu \mathrm{mol}$ photons $\mathrm{m}^{-2} \mathrm{~s}^{-1}$ with corresponding growth rates of 0.55 and $0.17 \mathrm{day}^{-1}$, respectively. Error bars denote standard deviations; $n=3$.

(PC), phosphatidylglycerol (PG), sulfoquinovosyldiacylglycerol (SQDG), MGDG and triacylglycerol (TAG) at the same photon flux density. The relative proportion in phosphatidylethanolamin (PE) and DGDG remained more or less constant (Table 3). 


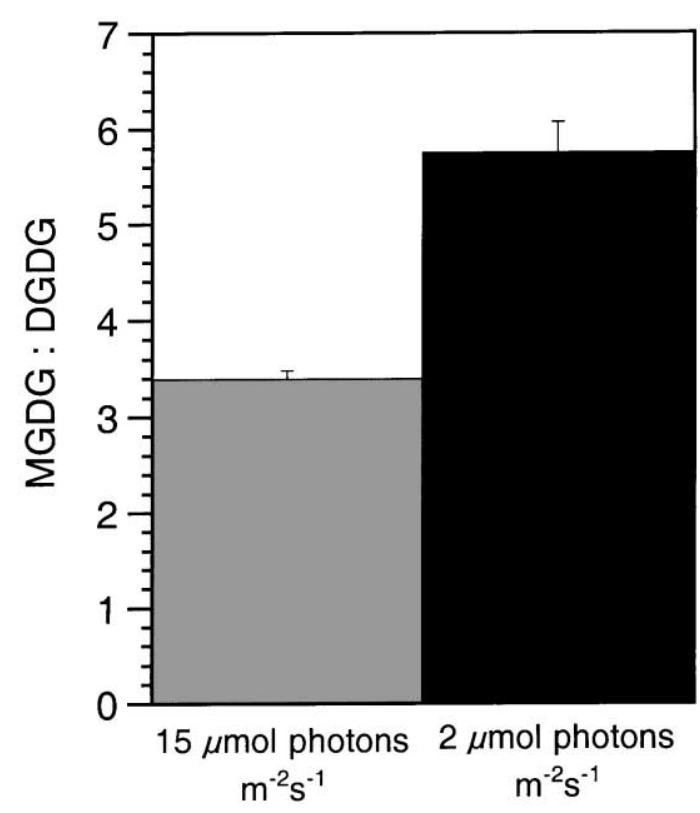

Fig. 6. Ratio of monogalactosyldiacylglycerol (MGDG) to digalactosydiacylglycerol (DGDG) under 15 and $2 \mu \mathrm{mol}$ photons $\mathrm{m}^{-2} \mathrm{~s}^{-1}$ with corresponding growth rates of 0.55 and $0.17 \mathrm{day}^{-1}$, respectively. Error bars denote standard deviations; $n=3$.

\section{Discussion}

Low photosynthetic active irradiance is one of the strongest determinants in the development and growth of ice algae. The efficiency of light utilization is expressed by high chl $a$ content, more so under $2 \mu \mathrm{mol}$ photons $\mathrm{m}^{-2} \mathrm{~s}^{-1}$ than under $15 \mu \mathrm{mol}$ photons $\mathrm{m}^{-2} \mathrm{~s}^{-1}$ (e.g. Falkowski and Owens, 1980). At $2 \mu \mathrm{mol}$ photons $\mathrm{m}^{-2}$ $\mathrm{s}^{-1}$ almost all carbon and organic nitrogen produced in the cell is converted into pigments and proteins for photosynthesis (Geider et al., 1996, 1998). Thus the flux of excitation energy into carbohydrates is strongly reduced under extreme low light conditions (Fig. 3). However, the pool of lipids, particularly the storage lipid triacylglycerol remained constant. This may be due to a minimum requirement for these lipids. The increase in cell chl $a$ under $2 \mu \mathrm{mol}$ photons $\mathrm{m}^{-2} \mathrm{~s}^{-1}$ was related to changes in photophysiology of PS II. $\alpha$ increased whereas photosynthesis was saturated at $102 \mu \mathrm{mol}$ photons $\mathrm{m}^{-2} \mathrm{~s}^{-1}$ in contrast to $158 \mu \mathrm{mol}$ photons $\mathrm{m}^{-2}$ $\mathrm{s}^{-1}$ at $15 \mu \mathrm{mol}$ photons $\mathrm{m}^{-2} \mathrm{~s}^{-1}$. Consequently, maximum attainable photosynthetic rate was reduced under $2 \mu \mathrm{mol}$ photons $\mathrm{m}^{-2} \mathrm{~s}^{-1}$ (Fig. 1).

The increase in photon trapping and generation of electrons at PS II under $2 \mu \mathrm{mol}$ photons $\mathrm{m}^{-2} \mathrm{~s}^{-1}$ was regulated by an increase in connectivity $\left(J_{\text {con }}\right)$ between reaction centres. The number of PS II and/or the LHC cross section probably increased in conjunction with an increase in chl $a$. One consequence, is a stronger probability of exciton capture by the reaction centres and thus a more efficient generation of electrons. Furthermore, the electron transport from reaction centres through the plastoquinone pool is faster under $2 \mu \mathrm{mol}$ photons $\mathrm{m}^{-2} \mathrm{~s}^{-1}$ which is indicated by rate constants $K_{A}, K_{B}, K_{C}$ and their amplitudes. The fluorescence amplitude for $A_{\text {comp }}$ remained relatively constant under both photon flux densities indicating a similar amount of $\mathrm{Q}_{\mathrm{B}}$ bound to $\mathrm{D} 1$, but the rate constants at $2 \mu \mathrm{mol}$ photons $\mathrm{m}^{-2} \mathrm{~s}^{-1}$ increased by about $50 \%$ compared to $15 \mu \mathrm{mol}$ photons $\mathrm{m}^{-2} \mathrm{~s}^{-1}$. Such an increase in electron transport velocity between bound $\mathrm{Q}_{\mathrm{A}}$ and $\mathrm{Q}_{\mathrm{B}}$ can be explained by increasing $\mathrm{FA}$ desaturation of typical chloroplast FAs (MGDG, SQDG, PG), particular by increasing 20:5 n-3 of MGDG and SQDG. These fatty acids support the $\mathrm{Q}_{\mathrm{A}}$ and $\mathrm{Q}_{\mathrm{B}}$ interactions and thus the velocity of electron flow (Horvath et al., 1987). In contrast, amplitudes for the $B_{\text {comp }}$ increased at $2 \mu \mathrm{mol}$ photons $\mathrm{m}^{-2} \mathrm{~s}^{-1}$ which is revealed by a larger amount of bound $\mathrm{Q}_{\mathrm{B}}$ and consequently a faster electron transport. Nevertheless, the major FA 20:5 n-3 of the chloroplast lipid class MGDG increased by ca. $50 \%$ in total fatty acids under $2 \mu \mathrm{mol}$ photons $\mathrm{m}^{-2} \mathrm{~s}^{-1}$ (Table 3 ) as well as pigments like chl $a / c$ (Fig. 2). This also supports the argument that chlorophyll molecules are associated with PUFA (Kates and Volcani, 1966; Cohen et al., 1988; Thompson et al., 1990). We suggest that diatoms use pairs of 20:5 to accommodate the phytol side chain of chl $a$. The desaturation of MGDG-FAs to 20:5n-3 was correlated with a shift to low photon flux densities and the activity of PS I. This adaptive response which provides alterations to lipid-protein interactions in the membrane may be important for the self-assembly of active chlorophyll-protein complexes for photosynthetic apparatus of PS I (Klyachko-Gurvich et al., 1999) and perhaps also for PS II.

Not only the presence of PUFAs in thylakoid membranes is important for structure and function of PS I and II, but the composition of lipid classes also significantly influences membrane structure (Block et al., 1983). Under $2 \mu \mathrm{mol}$ photons $\mathrm{m}^{-2} \mathrm{~s}^{-1}$, the concentration of non-bilayer forming MGDG increased in relation to other bilayer forming lipids, especially DGDG (Fig. 5). The ratio of 5.8 between both glycolipid classes is much higher than the critical ratio of 2.5 , above which transition to non-bilayer structures begins in MGD/ DGD mixtures (Sprague and Staehelin, 1984). We assume that the existence of thylakoid bilayers is required in sea ice diatoms just like in all other photosynthetic organisms. The existence of bilayers with such high proportions of non-bilayer-forming lipids is only possible when sufficient thylakoid pigment-protein complexes are present (Webb and Green, 1991). If more thylakoid pigment-protein complexes are present in the membranes, as found under light limitation, less bilayerforming lipids such as DGDG are required to stabilize the bilayer structure. Differences in protein content between both photon flux densities could be neglected due to insignificant changes in protein concentrations 

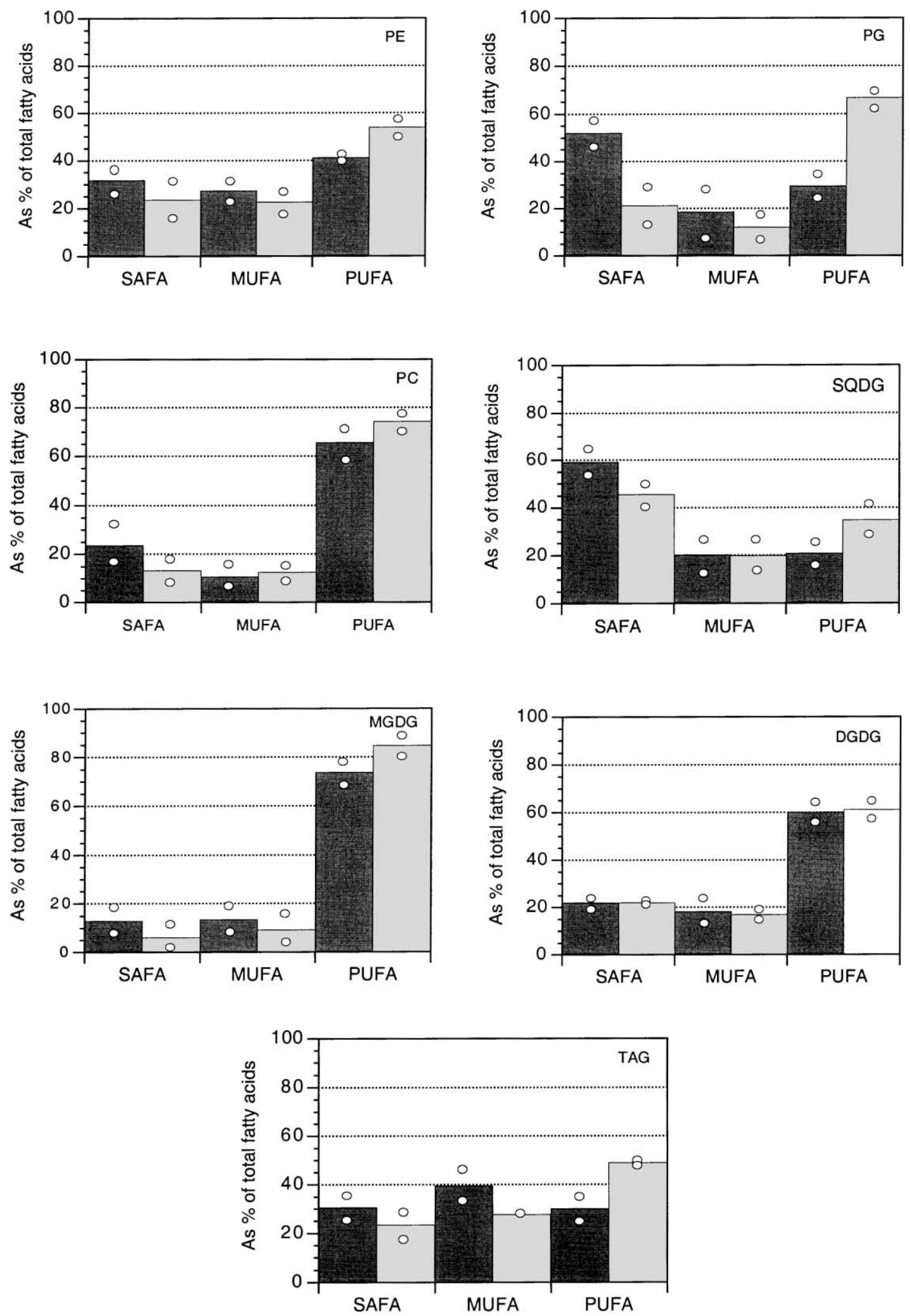

$15 \mu \mathrm{mol}$ photons $\mathrm{m}^{-2} \mathrm{~s}^{-1}$

$2 \mu \mathrm{mol}$ photons $\mathrm{m}^{-2} \mathrm{~s}^{-1}$

Fig. 7. Distribution of saturated (SAFA), monounsaturated (MUFA) and polyunsaturated fatty acids (PUFA) in lipid classes of sea ice diatoms as $\%$ of total particulate organic algal carbon under 15 and $2 \mu$ mol photons $\mathrm{m}^{2} \mathrm{~s}^{-1}$ with corresponding growth rates of 0.55 and 0.17 day ${ }^{-1}$, respectively; $n=2$. 
Table 3

Fatty acid composition in lipid classes of sea ice diatoms at $15 \mu \mathrm{mol}$ photons $\mathrm{m}^{-2} \mathrm{~s}^{-1}$ (growth rate 0.55 day $^{-1}$ ) and at $2 \mu \mathrm{mol}$ photons $\mathrm{m}^{-2} \mathrm{~s}^{-1}$ (growth rate 0.17 day $^{-1}$ )

\begin{tabular}{|c|c|c|c|c|c|c|c|c|c|c|c|c|c|c|}
\hline \multirow{2}{*}{$\begin{array}{l}\text { Fatty } \\
\text { acid }\end{array}$} & \multicolumn{2}{|l|}{$\mathrm{PC}$} & \multicolumn{2}{|l|}{$\mathrm{PE}$} & \multicolumn{2}{|l|}{ PG } & \multicolumn{2}{|l|}{ SQDG } & \multicolumn{2}{|l|}{ DGDG } & \multicolumn{2}{|l|}{ MGDG } & \multicolumn{2}{|l|}{ TAG } \\
\hline & $\begin{array}{l}15 \mu \mathrm{mol} \\
\text { photons } \\
\mathrm{m}^{-2} \mathrm{~s}^{-1}\end{array}$ & $\begin{array}{l}2 \mu \mathrm{mol} \\
\text { photons } \\
\mathrm{m}^{-2} \mathrm{~s}^{-1}\end{array}$ & $\begin{array}{l}15 \mu \mathrm{mol} \\
\text { photons } \\
\mathrm{m}^{-2} \mathrm{~s}^{-1}\end{array}$ & $\begin{array}{l}2 \mu \mathrm{mol} \\
\text { photons } \\
\mathrm{m}^{-2} \mathrm{~s}^{-1}\end{array}$ & $\begin{array}{l}15 \mu \mathrm{mol} \\
\text { photons } \\
\mathrm{m}^{-2} \mathrm{~s}^{-1}\end{array}$ & $\begin{array}{l}2 \mu \mathrm{mol} \\
\text { photons } \\
\mathrm{m}^{-2} \mathrm{~s}^{-1}\end{array}$ & $\begin{array}{l}15 \mu \mathrm{mol} \\
\text { photons } \\
\mathrm{m}^{-2} \mathrm{~s}^{-1}\end{array}$ & $\begin{array}{l}2 \mu \mathrm{mol} \\
\text { photons } \\
\mathrm{m}^{-2} \mathrm{~s}^{-1}\end{array}$ & $\begin{array}{l}15 \mu \mathrm{mol} \\
\text { photons } \\
\mathrm{m}^{-2} \mathrm{~s}^{-1}\end{array}$ & $\begin{array}{l}2 \mu \mathrm{mol} \\
\text { photons } \\
\mathrm{m}^{-2} \mathrm{~s}^{-1}\end{array}$ & $\begin{array}{l}15 \mu \mathrm{mol} \\
\text { photons } \\
\mathrm{m}^{-2} \mathrm{~s}^{-1}\end{array}$ & $\begin{array}{l}2 \mu \mathrm{mol} \\
\text { photons } \\
\mathrm{m}^{-2} \mathrm{~s}^{-1}\end{array}$ & $\begin{array}{l}15 \mu \mathrm{mol} \\
\text { photons } \\
\mathrm{m}^{-2} \mathrm{~s}^{-1}\end{array}$ & $\begin{array}{l}2 \mu \mathrm{mol} \\
\text { photons } \\
\mathrm{m}^{-2} \mathrm{~s}^{-1}\end{array}$ \\
\hline 14:0 & 7.46 & 3.44 & 8.40 & 11.65 & 21.37 & 2.43 & 22.80 & 8.87 & 8.17 & 13.48 & 4.66 & 3.07 & 9.65 & 11.00 \\
\hline $15: 0$ & - & 0.27 & 1.24 & 0.58 & - & - & - & - & - & 0.34 & 3.32 & 0.95 & 0.43 & 4.10 \\
\hline $16: 0$ & 14.12 & 8.95 & 21.02 & 10.81 & 30.60 & 16.94 & 28.58 & 15.84 & 10.81 & 7.63 & 3.50 & 1.70 & 19.34 & 7.10 \\
\hline 18:0 & 2.04 & 0.54 & 0.95 & 0.48 & - & 1.77 & 7.67 & 20.92 & 2.89 & 0.52 & 1.37 & 0.33 & 1.11 & 1.30 \\
\hline $16: 1 n-7$ & 7.30 & 8.69 & 23.53 & 20.11 & 11.88 & 6.31 & 20.21 & 19.74 & 8.45 & 13.30 & 8.72 & 6.23 & 36.02 & 24.76 \\
\hline $18: 1 n-9$ & 1.66 & 1.52 & - & - & - & 0.95 & - & - & 6.37 & 1.65 & 0.96 & 0.43 & 3.02 & 2.96 \\
\hline $18: 1 n-7$ & 1.82 & 1.92 & 3.77 & 2.50 & 6.60 & 4.95 & - & - & - & 1.08 & 0.83 & 0.73 & - & - \\
\hline $20: 1 n-9$ & - & 0.52 & - & - & - & - & - & - & 3.30 & 0.92 & 2.96 & 1.89 & 0.50 & - \\
\hline $16: 2 n-?$ & 2.87 & 0.40 & - & 1.00 & - & 0.85 & - & - & 10.59 & 3.11 & 2.48 & 1.03 & 1.69 & - \\
\hline $16: 3 n-?$ & - & 0.40 & - & 1.00 & - & - & - & - & - & 2.17 & 8.45 & 4.87 & 1.12 & - \\
\hline $16: 4 n-1$ & - & 0.50 & - & - & - & 0.52 & 9.46 & 12.63 & 4.45 & 9.10 & 35.41 & 33.84 & 1.57 & 2.08 \\
\hline $18: 2 n-6$ & 5.55 & 4.53 & 0.80 & 1.21 & - & 1.03 & - & - & - & 1.27 & 1.84 & 1.03 & 2.18 & 3.24 \\
\hline $18: 3 n-3$ & 2.98 & 0.63 & - & - & - & - & - & - & - & 0.60 & 2.38 & - & 0.91 & - \\
\hline $18: 4 n-3$ & 7.6 & 1.94 & - & - & 6.65 & - & - & - & 11.81 & 8.72 & - & 0.73 & 6.38 & 2.3 \\
\hline $20: 2 n-?$ & - & - & 13.36 & 18.48 & - & - & - & - & - & - & - & - & 1.47 & - \\
\hline $20: 4 n-6$ & - & 3.58 & - & 0.55 & - & 9.72 & - & - & - & 1.01 & - & 1.95 & - & - \\
\hline $20: 4 n-3$ & 1.62 & 1.08 & 3.20 & 11.12 & - & 1.18 & - & - & - & 2.81 & - & - & 1.08 & 2.27 \\
\hline $20: 5 n-3$ & 37.16 & 51.16 & 20.56 & 18.91 & 22.91 & 50.68 & 11.28 & 22.00 & 33.19 & 30.96 & 23.10 & 40.71 & 12.49 & 33.56 \\
\hline $22: 6 n-6$ & 7.82 & 9.92 & 3.15 & 1.62 & - & 2.66 & - & - & - & 1.31 & - & 0.79 & 1.04 & 5.38 \\
\hline
\end{tabular}

Results are reported as $\%$ of total fatty acids. $\mathrm{PC}=$ phosphatidylcholine; $\mathrm{PE}=$ phosphatidylethanolamin; $\mathrm{PG}=$ phosphatidylglycerol; $\mathrm{SQDG}=$ sulfoquinovosyldiacylglycerol; $\mathrm{DGDG}=$ digalactosyldiacylglycerol; $\mathrm{MGDG}=$ monogalactosyldiacylglycerol; TAG $=$ triacylglycerol. - Not detected; $n=2$.

(Fig. 3). Pigment contents which nearly doubled under 2 $\mu \mathrm{mol}$ photons $\mathrm{m}^{-2} \mathrm{~s}^{-1}$ must therefore be responsible for an increase in the MGDG:DGDG ratio.

Consequently, photon flux density as an important determinant for growth in polar diatoms, influences the amount of chl $a$ in the choloroplast, leading to biochemical changes of the chloroplast membranes in order to sustain intact bilayers and thus photosynthesis. Besides this influence of light on structural regulation of thylakoid membranes, light also regulates the fluidity of the thylakoid membrane.

\section{Experimental}

Material and methods which were applied in this investigation are identical to those in part I, described in: Photosynthetic energy conversion under extreme conditions: I. Important role of lipids as structural modulators and energy sink under $N$-limited growth in Antarctic sea ice diatoms (Mock and Kroon, 2002). Only the basic experimental conditions were changed as follows: two different photon flux densities were adjusted within continuous cultures: a total of $15.0 \pm 5.0$ $\mu \mathrm{mol}$ photons $\mathrm{m}^{-2} \mathrm{~s}^{-1}$ resulted in a growth rate of 0.55 day $^{-1}$ with a optical density (OD) of $0.11 \pm 0.01$. A photon flux density of $2.0 \pm 1.0 \mu \mathrm{mol}$ photons $\mathrm{m}^{-2} \mathrm{~s}^{-1}$ lead to an algal growth rate of 0.17 day $^{-1}$ with an OD of $0.037 \pm 0.006$. The algal composition in the first culture was $66 \pm 11 \%$ of Navicula gelida var. antarctica, $20 \pm 7 \%$ of Fragilariopsis curta and $14 \pm 9 \%$ of Nitzschia medioconstricta after ca. one week under steady state growth. At $2 \mu \mathrm{mol}$ photons $\mathrm{m}^{-2} \mathrm{~s}^{-1}$ and a growth rate of 0.17 day $^{-1}$ Navicula gelida var. antarctica constituted $65 \pm 6 \%$, Fragilariopsis curta $15 \pm 6 \%$ and Nitzschia medioconstricta $20 \pm 7 \%$ to the total community.

\section{Acknowledgements}

We are grateful to the crew of the RV Polarstern for their assistance during the expedition. We thank Gerhard Kattner and Martin Graeve for valuable discussions and for kind assistance with the lipids. Gerhard Dieckmann is thanked for reviewing an earlier version of the manuscript, and making suggestions for its improvement.

\section{References}

Block, M.A., Dorne, A.J., Joyard, J., Douch, R., 1983. Preparation and characterization of membrane fractions enriched in outer and inner envelope membranes from spinach chloroplasts. II Biochemical characterization. J. Biol. Chem. 258, 13281-13286. 
Cohen, Z., Vonshak, A., Richmond, A., 1988. Effect of environmental conditions on fatty acid composition of the red alga Porphyridium cruetum: correlation to growth rate. J. Phycol. 24, 328-332.

Eilers, P.H., Peters, J.C.H., 1988. A model for the relationship between light intensity and the rate of photosynthesis in phytoplankton. Ecol. Model. 42, 199-215.

Falkowski, P.G., Owens, T.G., 1980. Light shade adaptation: two strategies in marine phytoplankton. Plant Physiol. 66, 632-635.

Geider, R.J., MacIntyre, H.L., Kana, T.M., 1996. A dynamic model of photoadaptation in phytoplankton. Limnol. Oceanogr. 41, 1-15.

Geider, R.J., MacIntyre, H.L., Kana, T.M., 1998. Dynamic model of phytoplankton growth and acclimation: responses of the balanced growth rate and the chlorophyll a: carbon ratio to light, nutrientlimitation and temperature. Limnol. Oceanogr. 43 (4), 679-694.

Harwood, J.L., Jones, A.L., 1989. Lipid metabolism in algae. Adv. Bot. Res. 16, 1-53.

Horvárth, G., Melis, A., Hideg, E., Droppa, M., Vigh, L., 1987. Role of lipids in the organization and function of photosystem II studied by homogeneous catalytic hydrogenation of thylakoid membranes in situ. Biochim. Biophys. Acta 891, 68-74.

Huisman, J., Weissing, F.J., 1999. Biodiversity of plankton by species oscillations and chaos. Nature 402, 407-410.

Kates, M., Volcani, B.E., 1966. Lipid components of diatoms. Biochim. Biophys. Acta 116, 264-278.

Kirst, G.O., Wiencke, C., 1995. Ecophysiology of polar algae. J. Phycol. 31, 181-199.

Klyachko-Gurvich, G.L., Tsoglin, L.N., Doucha, J., Kopetskii, J., Ryabykh, I.B.S., Semenenko, V.E., 1999. Desaturation of fatty acids as an adaptive response to shifts in light intensity. Phys. Plant. 107, 240-249.

Krembs, C., Gradinger, R., Spindler, M., 2000. Implications of brine channel geometry and surface area for the interaction of sympagic organisms in Arctic sea ice. J. Exp. Mar. Biol. Ecol. 243, 55-80.
Mock, T, Kroon, B. M., 2002. Photosynthetic energy conversion under extreme conditions: I. Important role of lipids as structural modulators and energy sink under N-limited growth in Antarctic sea ice diatoms. Phytochemistry 61.

Pohl, F., Zurheide, 1979. Fatty acids and lipids of marine algae and the control of their biosynthesis by environmental factors. In: Hoppe, H.A., Levring, T., Tanaka, Y. (Eds.), Marine Algae in Pharmaceutical Science. Walter de Gruyter, Berlin, pp. 473-523.

Reay, D.S., Nedwell, D.B., Priddle, J., Ellis-Evans, C., 1999. Temperature dependence of inorganic nitrogen uptake: reduced affinity for nitrate at suboptimal temperatures in both algae and bacteria. Appl. Environ. Microbiol. 65, 2577-2584.

Russell, N.J., 1997. Psychrophilic bacteria-molecular adaptations of membrane lipids. Comp. Biochem. Physiol. 118A (3), 489-493.

Saruwatari, M., Takio, S., Ono, K., 1999. Low temperature-induced accumulation of eicosapentaenoic acids in Marchantia polymorpha cells. Phytochemistry 52, 367-372.

Sewon, P., Mikola, H., Lehtinen, T., Kallio, P., 1997. Polar lipids and net photosynthesis potential of subarctic Diapensia lapponica. Phytochemistry 46, 1339-1347.

Sprague, S.G., Staehelin, L.A., 1984. Effects of reconstitution method on the structural organization of isolated chloroplast membrane lipids. Biochim. Biophys. Acta 777, 306-433.

Tasaka, Y., Gombos, Z., Nishiyama, Y., Mohanty, P., Ohba, T., Ohki, K., Murata, N., 1996. Target mutagenesis of acyl-lipid desaturases in synechocystis: evidence for the important roles of polyunsaturated membrane lipids in growth, respiration and photosynthesis. EMBO J. 15, 6416-6425.

Thompson, P.A., Harrison, P.J., Whyte, J.N.C., 1990. Influence of irradiance on the fatty acid composition of phytoplankton. J. Phycol. 26, 278-288.

Webb, M.S., Green, B.R., 1991. Biochemical and biophysical properties of thylakoid acyl lipids. Biochim. Biophys. Acta 1060, 133-158. 